\title{
Butyltins compounds in molluscs from Chinese Bohai coastal waters
}

\author{
Ruiqiang Yang, Qunfang Zhou, Jiyan Liu, Guibin Jiang * \\ State Key Laboratory of Environmental Chemistry and Ecotoxicology, Research Center for Eco-Environmental Sciences, \\ Chinese Academy of Sciences, P.O. Box 2871, Beijing 100085, China
}

Received 12 July 2004; received in revised form 20 March 2005; accepted 20 March 2005

\begin{abstract}
Concentrations of butyltin compounds including tributyltin (TBT), dibutyltin (DBT) and monobutyltin (MBT) were determined in mollusc samples from Chinese Bohai coastal sites to evaluate the extent of contamination and potential adverse effects on health. Wide existence of butyltins was found in these samples with a detection rate of up to $90 \%$, and the concentrations of the total butyltin ( $\sum$ BTs: TBT + DBT + MBT) ranged from <2.5 to $397.6 \mathrm{ng} \mathrm{Sn} / \mathrm{g}$ wet weight (mean $63 \mathrm{ng} \mathrm{Sn} / \mathrm{g}$ ). Among BTs, TBT was the predominant compound in most of the samples, indicating ongoing usage of TBT-based antifouling agents in China. The different accumulation capabilities of BTs among various species were studied. The wide occurrence and serious pollution of BTs in seafood indicated a potential danger for the health of the local people who cared for these foods.
\end{abstract}

(c) 2005 Elsevier Ltd. All rights reserved.

Keywords: Antifouling paints; Monitoring; Organotin; Residues; Risk assessment; Seafood

\section{Introduction}

Butyltin compounds have been extensively used in consumer and industrial products such as polyvinyl chloride (PVC) stabilizers, industrial catalysts, agricultural biocides, wood preservatives, and antifouling agents in paints since the 1960s (Shim, Hong, Yim, Kim, \& Oh, 2002). TBT has received much attention due to its wide application in antifouling paints and the resulting direct pollution of the aquatic environment. It was well demonstrated that TBT could lead to a series of adverse effects such as imposex in neogastropods, shell deformations in oysters, and mortality of the larvae of mussels (Michael, 2002). BTs may affect human health through consumption of contaminated seafood. Therefore, monitoring contaminant residues in food is regarded as one of the key aspects to minimize the potential hazards to human health (Falandysz et al., 2004; Sawaya et al., 2000).

\footnotetext{
${ }^{*}$ Corresponding author. Tel.: +8610 62849334; fax: +8610 62849179. E-mail address: gbjiang@mail.rcees.ac.cn (G. Jiang).
}

A reduction of TBT contamination was recorded after a restriction was placed on the usage of TBT-based antifouling paints in most developed countries (Konstantinou \& Albanis, 2004). However, butyltin compounds are still persistent in aquatic ecosystems, particularly in areas with intensive docking activities as well as possible industrial discharges (Morcillo \& Porte, 1998). In fact, the restriction is inadequate; TBT is still being used in antifouling paints applied to larger ships ( $>25 \mathrm{~m}$ in length) in most developed countries, and no restriction has been implemented on the usage in most Asian developing countries, including China. Particular concern should be placed on these regions because dramatic economic growth and increasing demand for antifouling agents may lead to deleterious environmental effects. According to the resolution of the International Maritime Organization (IMO) meeting in October 2001, a global prohibition has been placed on the application of organotin compounds used as antifouling paints additives on ships by January 1, 2003, and a complete prohibition by January 1, 2008 (Rüdel, Lepper, \& Steinhanses, 2003). It is urgent and necessary 
to cause more public concern on organotin pollution and to promote the related legislative process by the government.

The Bohai Sea is off the coast of north China which is one of the country's most populous and developed areas and is a major oceanic fishery. However, with rapid economic growth, it is inevitable that serious aquatic pollution is caused. In the present study, 113 mollusc samples including 13 different species were collected from 13 typical coastal sites along the China Bohai Sea. These species are extensively distributed along the Chinese coast. Most of the samples were commercially valuable seafood and were highly suitable for the culture in these coastal areas. Having high protein contents, this seafood is a popular diet for local people. However, to our knowledge, the data on butyltins pollution in molluscs of Bohai are rather limited. The present study aims to reveal the status of contamination of BTs and their distribution in coastal waters of China-Bohai; and to evaluate the potential risk of the contaminated seafood for the peoples' health.

\section{Materials and methods}

\subsection{Study area}

Fig. 1 shows the sampling sites along Chinese Bohai coast. The sampling sites were located in the northeast of China, which has highly developed heavy industries and fishing culture; Therefore, serious environmental pollution might occur in these semi-enclosed aquatic systems. Most of the mollusc samples were collected from the important seaports having heavy traffic. The samples of Yingkou were collected mostly from fishery

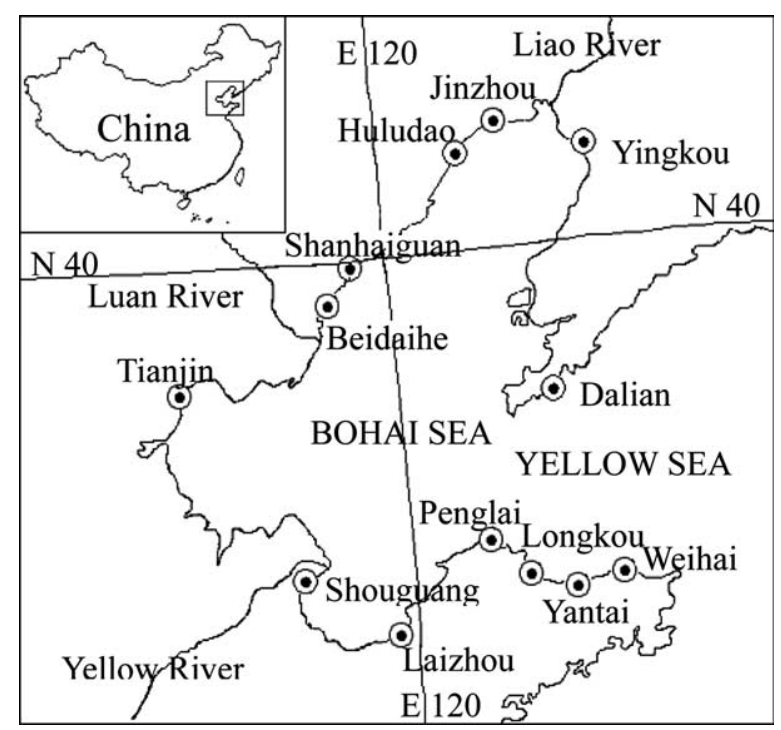

Fig. 1. The sampling locations of molluscs. areas, while those from Shouguang, a small port were relative far from the possible seriously polluted areas.

\subsection{Sample collection and preparation}

Mollusc samples including various species of bivalves and snails were collected during July-August, 2003. Different species were carefully identified according to the catalog of marine molluscs in reference books (Zhao, Cheng, \& Zhao, 1982). Samples were stored in butytin-free polyethylene bags, kept in an ice-cooled box during the transportation and then immediately stored at $-20{ }^{\circ} \mathrm{C}$ in the refrigerator. Before analysis, the samples were firstly unshelled and the soft tissues were pooled and thoroughly rinsed with de-ionized water to remove extraneous impurities. After obtaining a sufficient homogenate using a stainless blender, the sub-samples were used for analysis.

\subsection{Instrumental analysis}

The concentrations of butyltin compounds were determined using a GC-9A gas chromatograph (Shimadzu, Japan). A HP-1 fused-silica capillary column $(25 \mathrm{~m} \times 0.32 \mathrm{~mm} \times 0.17 \mu \mathrm{m})$ was used to separate the organotin compounds. The oven temperature was raised from $100{ }^{\circ} \mathrm{C}$ (hold for $1 \mathrm{~min}$ ) to $180^{\circ} \mathrm{C}$ (hold for $5 \mathrm{~min}$ ) at $5{ }^{\circ} \mathrm{C} / \mathrm{min}$. The temperatures of the injector and the detector were controlled at 220 and $160{ }^{\circ} \mathrm{C}$, respectively. High pure nitrogen served as carrier gas and was kept at the pressure of $0.26 \mathrm{MPa}$ on the column head. The detection was accomplished by a laboratory-made flame photometric detector using quartz surface-induced luminescence (QSIL-FPD) equipped with a 394-nm interference filter. A SC-1100 PC data processing system was used for data analysis.

\subsection{Standards and reagents}

The standards including tetrabutyltin (TeBT, 96\%), tributyltin chloride (TBT, 90\%), dibutyltin dichloride (DBT, 97\%) and monobutyltin trichloride (MBT, 97\%) were purchased from Acros Organics (NJ, USA). TeBT was used as an internal standard. The stock solutions with a concentration of $1 \mathrm{mg} \mathrm{Sn} / \mathrm{ml}$ were obtained by dissolving the accurately weighed TeBT, TBT, DBT and MBT into methanol, respectively. The $\mathrm{pH}$ value was adjusted to 2 with concentrated $\mathrm{HCl}$ to ensure its stability. Working standard solutions were freshly made before analysis. All the solutions were stored at $4{ }^{\circ} \mathrm{C}$ in the dark. The Grignard reagent of $n$-propylmagnesium bromide ( $n$-PrMgBr, ca. 2.0 M, in ether) was synthesized according to the method (Zhou, Jiang, \& Qi, 1999). All reagents used were of analytical reagent grade or better. Glassware was rinsed with de-ionized water, decontaminated overnight in 1:1 nitric acid solution and then rinsed again. 


\subsection{Analytical procedure}

The analytical procedure was similar to the method, which had been confirmed by determination of the certified reference material (CRM477) (Jiang, Maxwell, Siu, Luong, \& Berman, 1991). Briefly, about 2-g sample was used for analysis of butyltin compounds. After it was mixed with a suitable amount of internal standard TeBT, $10 \mathrm{ml}$ of THF-HCL (11:1) solution was added and then extracted with $25 \mathrm{ml} 0.01 \%(\mathrm{~m} / \mathrm{v})$ tropolonehexane solution under vigorous shaking for $40 \mathrm{~min}$. The extracts were decanted, another $10 \mathrm{ml}$ of hexane was added to the original homogenate, and the mixture again shaken for $20 \mathrm{~min}$. The combined extract was concentrated on a rotary evaporator to about $2-3 \mathrm{ml}$ and submitted to Grignard propylation. The analytes was purified using a glass column packed with anhydrous $\mathrm{Na}_{2} \mathrm{SO}_{4}(2 \mathrm{~g})$, Silica gel $(2 \mathrm{~g})$ and Florisil $(2 \mathrm{~g})$ in turn from the top. The final volume was adjusted to $1.0 \mathrm{ml}$ under a gentle stream of pure nitrogen. Procedural blanks were processed with every batch of samples, they were all free from organotin contamination or other interferences. Detection limit (assigned 3 times signal/ noise) of TBT, DBT, MBT were 2.8, 3.2, $2.5 \mathrm{ng} \mathrm{Sn} / \mathrm{g}$ wet weight, respectively.

\section{Results and discussion}

\subsection{Contamination status}

Butyltin concentrations including TBT, DBT, MBT and their total values ( $\sum \mathrm{BTs}$ ) of all the samples were summarized in Table 1 as nanograms of Sn per $\mathrm{g}$ on a wet weight basis. The detection rate was about $90 \%$ wherein among 113 samples, 101 of the samples were found to contain detectable BTs, which indicated a wide incidence of BTs pollution along the Chinese Bohai coast. Concentrations of $\sum B$ Ts ranged from the determination limit $(<2.5)$ to $397.6 \mathrm{ng} \mathrm{Sn} / \mathrm{g}$ (mean $63 \mathrm{ng} \mathrm{Sn} /$ g). The concentrations of TBT, DBT and MBT ranged from $<2.8$ to $383.9,<3.2$ to 158.1 and $<2.5$ to $52.2 \mathrm{ng} \mathrm{Sn} / \mathrm{g}$, respectively. Among BTs, TBT was detected at relatively high concentrations in most of samples, whereas the concentrations of DBT and MBT were low (Fig. 2). The concentration of TBT accounts for $45-100 \%$ of the total butyltin concentration (mean $75 \%$ ). The high level of butyltin compounds and high percentage of TBT implied fresh input of TBT in Chinese coastal sites, which is probably attributable to the continuous usage of TBT-based antifouling paints in China.

BTs residue levels in the mollusc samples varied with different sampling sites (shown in Fig. 2). The highest mean BTs level of up to $108 \mathrm{ng} \mathrm{Sn} / \mathrm{g}$ was found in the samples collected from Dalian, which is one of the important seaports of China and a world-famous tourist destination with consequently high density of various ships and boat. TBT resulting from the release of antifouling paints applied on the boats and ships due to the intensive maritime activities might account for the currently high BTs contents in Dalian mollusc samples. The lowest residue level of BTs (mean $\sum$ BTs $17.2 \mathrm{ng} \mathrm{Sn} /$ g) was detected in Shouguang samples, which were collected at relatively clean sites. Noticeably, most of the samples from Yingkou, a marine aquaculture area away from the seaport, were also characterised by high contents of butyltin compounds (mean $\sum B$ Ts $37.8 \mathrm{ng} \mathrm{Sn} /$ g). It was found that TBT-based coatings on the marine aquaculture facilities, such as fishnets and sea pens, could be one of the sources for BTs in the cultured area. High levels of BTs were also found in the other sampling sites, which were all port cities possessing a high density of ships coated with TBT-based antifouling paints.

A number of studies providing monitoring data of BTs residues are available so that a comparison with the pollution situation of the sampling area over the world is possible (Table 2). When TBT concentrations in mussels were compared with those in some antifouling paints-banned countries such as USA, Australia, Canada and Japan, relatively high residue levels were found in the China Bohai coast. Among Asian developing countries considered, BTs levels in mussels from the coastal waters of Korea, China, Philippines and Thailand were in the higher range compared with those from India, Malaysia and Hong Kong. It should be noted that the demand for TBT-based marine coating paints in these countries is currently increasing (Hong, Takahashi, Min, \& Tanabe, 2002). In addition, because of the unregulated application of BTs in many Asian developing countries such as China, India, Thailand and the Philippines, as well as other nearby developing countries, BTs contamination in the Asian aquatic environment may become increasingly serious in future. Consequently, effective actions should be taken as soon as possible.

\subsection{Bio-accumulation of organisms}

According to the results shown in Table 1, it was easy to find that the accumulation concentrations of butyltin compounds varied in different species, even when they were collected from the same sites. For instance, in Beidaihe samples, the highest $\sum$ BTs content of $397.6 \mathrm{ng} \mathrm{Sn} / \mathrm{g}$ was found in Mya arenaria, whereas the lowest was only $14.0 \mathrm{ng} \mathrm{Sn/g}$ in Amusium. Fig. 3 shows the mean bio-accumulation concentration of $\sum \mathrm{BT}$ s in various species. The comparative organisms belonged to the most popular seafood items and were widely distributed along Chinese coastal sites. The detection rate of BTs ranged from $50 \%$ to $100 \%$ and several species such as M. arenaria, Meretrix meretrix, Mytilus edulis, 
Table 1

Butyltin concentrations (ng Sn/g ww) in molluscs from Chinese Bohai coastal sites

\begin{tabular}{|c|c|c|c|c|c|}
\hline Locations & Species & MBT & DBT & TBT & $\sum \mathrm{BTS}$ \\
\hline \multirow[t]{11}{*}{ Dalian } & Rapana venosa (Valenciennes, 1846) & nd & 2.7 & 42.2 & 44.9 \\
\hline & Neverita didyma (Röeding, 1848) & 16.7 & 30.9 & 14.9 & 62.5 \\
\hline & Crassostrea gigas (Crosse, 1862) & 21.3 & 26.1 & 205.8 & 253.3 \\
\hline & Mytilus edulis (Linnaeus, 1758) & 9.8 & 10.3 & 183.5 & 203.6 \\
\hline & Amusium (Röding, 1798) & nd & nd & 32.4 & 32.4 \\
\hline & Chlamys farreri (Jones and Preston, 1904) & 12.3 & 18.1 & 358.0 & 388.4 \\
\hline & Scapharca subcrenata (Schrenck, 1869) & nd & nd & 12.4 & 12.4 \\
\hline & Sinonovacula constricta (Lamarck, 1818) & 5.6 & 23.2 & 137.8 & 166.6 \\
\hline & Ruditapes philippinarum (Adams and Reeve, 1850) & 3.1 & 2.9 & 49.0 & 54.9 \\
\hline & Mactra veneriformis (Reeve, 1854) & 18.7 & 11.6 & 48.2 & 78.5 \\
\hline & Meretrix meretrix (Linnaeus, 1758) & nd & 6.6 & 64.8 & 71.4 \\
\hline \multirow[t]{8}{*}{ Yingkou } & Neptunea cumingi (Crosse, 1862) & nd & nd & nd & nd \\
\hline & Mytilus edulis (Linnaeus, 1758) & 14.5 & 6.6 & 29.2 & 50.3 \\
\hline & Amusium (Röding, 1798) & nd & nd & nd & nd \\
\hline & Chlamys farreri (Jones and Preston, 1904) & nd & 14.8 & 42.2 & 57.0 \\
\hline & Scapharca subcrenata (Schrenck, 1869) & 11.8 & 14.1 & 23.3 & 49.2 \\
\hline & Ruditapes philippinarum (Adams and Reeve, 1850) & nd & nd & 25.6 & 25.6 \\
\hline & Mactra veneriformis (Reeve, 1854 ) & 9.9 & 15.9 & 44.8 & 70.6 \\
\hline & Meretrix meretrix (Linnaeus, 1758) & nd & 18.3 & 31.5 & 49.7 \\
\hline \multirow[t]{10}{*}{ Jinzhou } & Rapana venosa (Valenciennes, 1846) & 3.2 & nd & 19.2 & 22.4 \\
\hline & Neverita didyma (Röeding, 1848) & 8.3 & 7.2 & 11.0 & 26.6 \\
\hline & Crassostrea gigas (Crosse, 1862) & nd & nd & 68.7 & 68.7 \\
\hline & Mytilus edulis (Linnaeus, 1758) & 7.4 & 10.3 & 32.8 & 50.6 \\
\hline & Amusium (Röding, 1798) & nd & nd & nd & nd \\
\hline & Scapharca subcrenata (Schrenck, 1869) & 6.4 & 19.0 & 18.4 & 43.8 \\
\hline & Sinonovacula constricta (Lamarck, 1818) & nd & 64.4 & 46.9 & 111.3 \\
\hline & Ruditapes philippinarum (Adams and Reeve, 1850) & nd & nd & 7.1 & 7.1 \\
\hline & Mactra veneriformis (Reeve, 1854$)$ & 18.3 & 35.9 & 23.4 & 77.5 \\
\hline & Meretrix meretrix (Linnaeus, 1758) & 4.7 & 16.5 & 80.6 & 101.8 \\
\hline \multirow[t]{9}{*}{ Huludao } & Rapana venosa (Valenciennes, 1846) & nd & nd & 7.0 & 7.0 \\
\hline & Neverita didyma (Röeding, 1848) & nd & nd & 7.5 & 7.5 \\
\hline & Crassostrea gigas (Crosse, 1862) & 12.6 & 19.8 & 193.2 & 225.6 \\
\hline & Amusium (Röding, 1798) & nd & 6.0 & 14.8 & 20.8 \\
\hline & Scapharca subcrenata (Schrenck, 1869) & nd & nd & nd & nd \\
\hline & Sinonovacula constricta (Lamarck, 1818) & 45.2 & 71.9 & nd & 117.1 \\
\hline & Ruditapes philippinamm (Adams and Reeve, 1850) & nd & nd & 7.6 & 7.6 \\
\hline & Mactra veneriformis (Reeve, 1854$)$ & nd & 10.7 & 18.6 & 29.3 \\
\hline & Meretrix meretrix (Linnaeus, 1758) & 8.7 & 44.7 & 184.9 & 238.4 \\
\hline \multirow[t]{6}{*}{ Shanhaiguan } & Rapana venosa (Valenciennes, 1846) & nd & nd & 14.6 & 14.6 \\
\hline & Mytilus edulis (Linnaeus, 1758) & 31.0 & 36.8 & 46.6 & 114.4 \\
\hline & Amusium (Röding, 1798) & nd & nd & nd & nd \\
\hline & Sinonovacula constricta (Lamarck, 1818) & 11.9 & 10.2 & nd & 22.1 \\
\hline & Mactra veneriformis (Reeve, 1854) & 24.5 & 14.7 & 25.5 & 64.7 \\
\hline & Ruditapes philippinarum (Adams and Reeve, 1850) & 52.2 & 158.1 & 185.0 & 395.3 \\
\hline \multirow[t]{8}{*}{ Beidaihe } & Rapana venosa (Valenciennes, 1846) & 7.0 & 13.4 & 47.2 & 67.6 \\
\hline & Neverita didyma (Röeding, 1848) & 7.7 & 12.1 & 20.5 & 40.3 \\
\hline & Crassostrea gigas (Crosse, 1862) & nd & 7.1 & 36.9 & 44.0 \\
\hline & Mytilus edulis (Linnaeus, 1758) & nd & 8.4 & 23.2 & 31.7 \\
\hline & Amusium (Röding, 1798) & 0.6 & nd & 13.5 & 14.0 \\
\hline & Sinonovacula constricta (Lamarck, 1818) & 21.1 & 30.7 & nd & 51.8 \\
\hline & Mya arenaria (Linnaeus, 1758) & 5.5 & 8.2 & 383.9 & 397.6 \\
\hline & Mactra veneriformis (Reeve, 1854) & nd & nd & 56.4 & 56.4 \\
\hline \multirow[t]{8}{*}{ Tianjin } & Rapana venosa (Valenciennes, 1846) & 7.6 & 8.4 & 126.6 & 142.5 \\
\hline & Neverita didyma (Röeding, 1848) & 23.8 & 35.4 & 24.4 & 83.6 \\
\hline & Crassostrea gigas (Crosse, 1862) & 3.8 & 9.5 & 126.8 & 140.1 \\
\hline & Mytilus edulis (Linnaeus, 1758) & 10.2 & 7.7 & 137.3 & 155.3 \\
\hline & Amusium (Röding, 1798) & 5.3 & 4.4 & 12.1 & 21.8 \\
\hline & Scapharca subcrenata (Schrenck, 1869) & 6.5 & 17.9 & 39.1 & 63.6 \\
\hline & Sinonovacula constricta (Lamarck, 1818) & 15.2 & 3.5 & 8.6 & 27.3 \\
\hline & Meretrix meretrix (Linnaeus, 1758) & nd & 5.6 & 37.5 & 43.1 \\
\hline
\end{tabular}


Table 1 (continued)

\begin{tabular}{|c|c|c|c|c|c|}
\hline Locations & Species & MBT & DBT & TBT & $\sum \mathrm{BTs}$ \\
\hline \multirow[t]{6}{*}{ Shouguang } & Neverita didyma (Röeding, 1848) & nd & nd & 20.4 & 20.4 \\
\hline & Scapharca subcrenata (Schrenck, 1869) & nd & nd & nd & nd \\
\hline & Sinonovacula constricta (Lamarck, 1818) & nd & nd & nd & nd \\
\hline & Ruditapes philippinarum (Adams\&Reeve, 1850) & 8.0 & 14.7 & 17.6 & 40.3 \\
\hline & Mactra veneriformis (Reeve, 1854) & 12.0 & 8.5 & 12.1 & 32.7 \\
\hline & Meretrix meretrix (Linnaeus,1758) & nd & nd & 10.1 & 10.1 \\
\hline \multirow[t]{8}{*}{ Longkou } & Rapana venosa (Valenciennes, 1846) & 8.5 & 21.5 & 42.9 & 73.0 \\
\hline & Neverita didyma (Röeding, 1848) & 12.4 & 13.3 & 31.4 & 57.0 \\
\hline & Crassostrea gigas (Crosse, 1862) & 12.6 & 11.6 & 45.0 & 69.2 \\
\hline & Mytilus edulis (Linnaeus, 1758) & 11.3 & 24.7 & 69.9 & 105.9 \\
\hline & Scapharca subcrenata (Schrenck, 1869) & 7.8 & 12.6 & 54.9 & 75.2 \\
\hline & Sinonovacula constricta (Lamarck, 1818) & nd & nd & 8.1 & 8.1 \\
\hline & Ruditapes philippinarum (Adams and Reeve, 1850) & nd & nd & nd & nd \\
\hline & Meretrix meretrix (Linnaeus, 1758) & 8.6 & 16.7 & 177.8 & 203.0 \\
\hline \multirow{9}{*}{ Laizhou } & Rapana venosa (Valenciennes, 1846) & 3.5 & 3.6 & 10.0 & 17.0 \\
\hline & Neverita didyma (Röeding, 1848) & 33.1 & 43.9 & 82.5 & 159.6 \\
\hline & Crassostrea gigas (Crosse, 1862) & 4.4 & 13.3 & 20.2 & 37.9 \\
\hline & Mytilus edulis (Linnaeus, 1758) & 5.5 & 8.6 & 31.4 & 45.5 \\
\hline & Amusium (Röding, 1798) & nd & nd & nd & nd \\
\hline & Scapharca subcrenata (Schrenck, 1869) & 18.2 & 23.2 & 81.2 & 122.6 \\
\hline & Sinonovacula constricta (Lamarck, 1818) & nd & nd & nd & nd \\
\hline & Ruditapes philippinarwn (Adams and Reeve, 1850) & nd & nd & 7.5 & 7.5 \\
\hline & Mactra veneriformis (Reeve, 1854$)$ & 10.9 & 11.4 & 55.5 & 77.7 \\
\hline \multirow[t]{9}{*}{ Penglai } & Neptunea cumingi (Crosse, 1862) & nd & 12.8 & nd & 12.8 \\
\hline & Rapcma venosa (Valenciennes, 1846) & 3.1 & 24.2 & 20.5 & 47.8 \\
\hline & Neverita didyma (Röeding, 1848) & 3.2 & 19.6 & 40.1 & 62.9 \\
\hline & Crassostrea gigas (Crosse, 1862) & nd & 10.8 & 44.6 & 55.4 \\
\hline & Mytilus edulis (Linnaeus, 1758) & nd & 11.1 & 35.1 & 46.2 \\
\hline & Chlamys farreri (Jones and Preston, 1904) & 8.5 & 9.7 & 27.5 & 45.8 \\
\hline & Sinonovacula constricta (Lamarck, 1818) & nd & 12.8 & 97.0 & 109.8 \\
\hline & Ruditapes philippinarum (Adams and Reeve, 1850) & 8.6 & 13.6 & 41.4 & 63.5 \\
\hline & Mactra veneriformis (Reeve, 1854$)$ & nd & nd & nd & nd \\
\hline \multirow[t]{11}{*}{ Yantai } & Neptunea cumingi (Crosse, 1862) & 2.6 & 10.7 & nd & 13.3 \\
\hline & Rapana venosa (Valenciennes, 1846) & nd & 10.3 & nd & 10.3 \\
\hline & Neverita didyma (Röeding, 1848) & 4.6 & 16.3 & 14.7 & 35.6 \\
\hline & Crassostrea gigas (Crosse, 1862) & 24.6 & 32.3 & 101.4 & 158.2 \\
\hline & Mytilus edulis (Linnaeus, 1758) & 3.4 & 40.4 & 72.6 & 116.5 \\
\hline & Amusium (Röding, 1798) & nd & 22.7 & 10.7 & 33.4 \\
\hline & Chlamys farreri (Jones and Preston, 1904) & 2.3 & 3.1 & 8.7 & \\
\hline & Scapharca subcrenata (Schre.nck, 1869) & nd & 13.2 & 8.6 & 21.7 \\
\hline & Sinonovacula constricta (Lamarck, 1818) & nd & nd & nd & nd \\
\hline & Ruditapes philippinarum (Adams and Reeve, 1850) & nd & 5.9 & 11.3 & 17.1 \\
\hline & Meretrix meretrix (Linnaeus, 1758) & 14.7 & 6.7 & 59.0 & 80.3 \\
\hline \multirow[t]{10}{*}{ Weihai } & Neptunea cumingi (Crosse, 1862) & 5.2 & 16.7 & 11.5 & 33.4 \\
\hline & Rapana venosa (Valenciennes, 1846) & 2.1 & 8.5 & 13.9 & 24.5 \\
\hline & Neverita didyma (Röeding, 1848) & 25.5 & 17.1 & 25.5 & 68.1 \\
\hline & Crassostrea gigas (Crosse, 1862) & 3.5 & 7.5 & 103.9 & 114.9 \\
\hline & Mytilus edulis (Linnaeus, 1758) & 3.0 & 12.7 & 90.6 & 106.2 \\
\hline & Amusium (Röding, 1798) & nd & 3.4 & 26.7 & 30.1 \\
\hline & Chlamys farreri (Jones and Preston, 1904) & 1.8 & 2.4 & 12.1 & 16.3 \\
\hline & Scapharca subcrenata (Schrenck, 1869) & nd & nd & 19.6 & 19.6 \\
\hline & Sinonovacula constricta (Lamarck, 1818) & 5.7 & 7.0 & 70.0 & 82.7 \\
\hline & Ruditapes philippinarum (Adams and Reeve, 1850) & nd & nd & 13.0 & 13.0 \\
\hline
\end{tabular}

nd: below the detection limit.

Crassostrea gigas, Rapana venosa, Chlamys farreri and Neverita didyma having detection rates of up to $100 \%$, indicating that most of the molluscs are sensitive to accumulation of BTs compounds from the aquatic ecosystem. It should be noted that a much higher mean con- centration (310.7 $\mathrm{ng} \mathrm{Sn} / \mathrm{g}$ ) was found in $M$. arenaria compared with that of other species, which showed this species might have a stronger ability to accumulate organotin compounds from the coastal environment. In contrast, the bivalve Amusium and snail Neptunea 


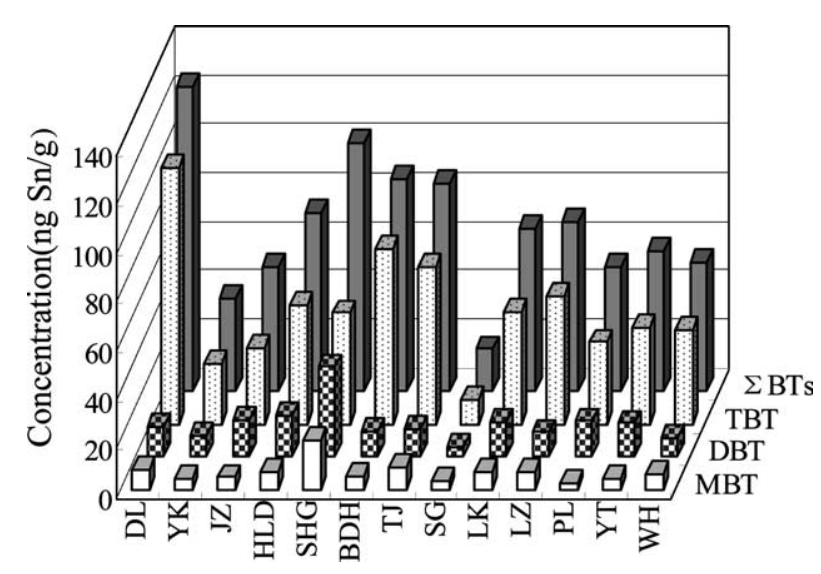

Fig. 2. Distribution and patterns of BTs in molluscs from the Chinese Bohai coastal sites (DL: Dalian, YK: Yingkou, JZ: Jinzhou, HLD: Huludao, SHG: Shanhaiguan, BDH: Beidaihe, TJ: Tianjin, SG: Shouguang, LZ: Laizhou, PL: Penglai, LK: Longkou, YT: Yantai, WH: Weihai).

cumingi seemed to easily eliminate these pollutants because of the lowest $\sum$ BTs level (15.3 and $13.8 \mathrm{ng} \mathrm{Sn} / \mathrm{g}$, respectively). As a whole, accumulation of contaminants by an organism might be affected by many factors such as method of uptake of the substances from the surrounding environment, and excretion rate.

\subsection{Risk assessment for the seafood}

It was well documented that some of organotin compounds acted as endocrine disrupters, at least in sensitive molluscs (De Mora, Fowler, Cassi, \& Tolosa, 2003). The threshold level for imposex in dogwhelks (Nucella lapillus) was approximately $0.5 \mathrm{ng} \mathrm{Sn} / 1$ for TBT (Gibbs \& Bryan, 1996). According to the previous

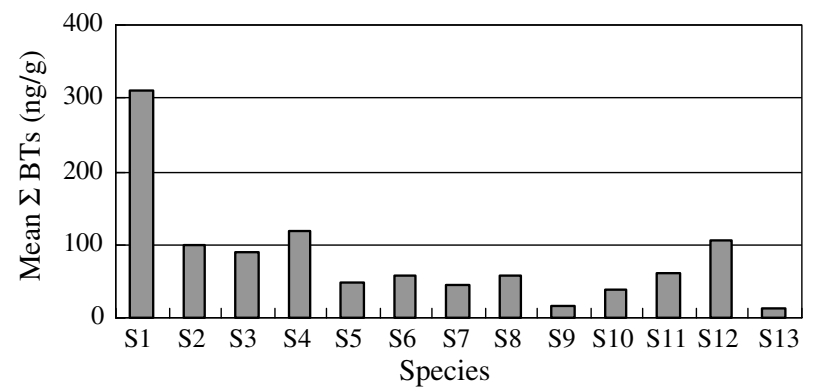

Fig. 3. Comparisons of mean $\sum \mathrm{BT}$ levels in different organisms. S1: Mya arenaria, S2: Meretrix meretrix, S3: Mytilus edulis, S4: Crassostrea gigas, S5: Mactra veneriformis, S6: Ruditapes philippinarum, S7: Scapharca subcrenata, S8: Sinonovacula constricta, S9: Amusium, S10: Rapana venosa, S11: Neverita didyma, S12: Chlamys farreri, S13: Neptunea cumingi.

results that TBT concentration ranged from $<0.5$ to $976.9 \mathrm{ng} \mathrm{Sn} / 1$ in Chinese coastal waters (Jiang, Zhou, Liu, \& Wu, 2001), some molluscs may suffer the high toxicity risk from organotin exposure. It was also found that organotin compounds could induce immunotoxicity, neurotoxicity, skin and eye irritation, mutagenicity, and carcinogenicity in mammals (Fent, 1996). Seafood, as one of the primary sources of protein, composes an important part of the diet for people around the world. BTs may directly affect human health via contaminated seafood. A study has reported measurable butyltin compounds in the human liver from Poland, presumably due to seafood consumption (Kannan \& Falandysz, 1997). Although the toxicology of organotin compounds in humans is not fully resolved (WHO, 1990), a related toxicity test can be extrapolated from animals to humans. Based on the observed effects of TBT on the immune function in rats with a safety factor of 100 , Penninks (1993) derived a tolerable daily intake (TDI) of TBT

Table 2

Comparison of TBT concentrations (ng TBT/g wet weight) ${ }^{\mathrm{a}}$ in worldwide bivalve molluscs

\begin{tabular}{|c|c|c|c|c|}
\hline Species & Location & Sampling date & TBT conc. & References \\
\hline Mytilus edulis & $\begin{array}{l}\text { West coast, USA } \\
\text { East coast, USA } \\
\text { Perth, Australia } \\
\text { Coastal harbour, Canada } \\
\text { Polish coast, Poland } \\
\text { Otsuchi Bay, Japan } \\
\text { Osaka port, Japan } \\
\text { South and East coast, Korea } \\
\text { Chinhae Bay, Korea } \\
\text { Bohai coast, China }\end{array}$ & $\begin{array}{l}1988-1990 \\
1988-1990 \\
1991 \\
1995 \\
1998 \\
1996 \\
1996 \\
1997-1999 \\
1994 \\
2002\end{array}$ & $\begin{array}{l}2-276 \\
2-2-40 \\
<1-330 \\
10-585 \\
6.6-166 \\
40-180 \\
24-389 \\
17-1200 \\
59-590 \\
57-495\end{array}$ & $\begin{array}{l}\text { Uhler et al. (1993) } \\
\text { Uhler et al. (1993) } \\
\text { Hong et al. (2002) } \\
\text { Chau et al. (1997) } \\
\text { Albalat et al. (2002) } \\
\text { Harino et al. (1998) } \\
\text { Harino et al. (1998) } \\
\text { Hong et al. (2002) } \\
\text { Hwang et al. (1999) } \\
\text { This study }\end{array}$ \\
\hline Perna viridis & $\begin{array}{l}\text { Hong Kong } \\
\text { Malaysia } \\
\text { Thailand } \\
\text { India } \\
\text { Philippines }\end{array}$ & $\begin{array}{l}1989 \\
1992 \\
1994-1995 \\
1994-1995 \\
1994-1997\end{array}$ & $\begin{array}{l}64-115 \\
14-24 \\
3-680 \\
<1-150 \\
<1-640\end{array}$ & $\begin{array}{l}\text { Chin et al. (1991) } \\
\text { Tong et al. (1996) } \\
\text { Kan-atireklap et al. (1998) } \\
\text { Kan-atireklap et al. (1998) } \\
\text { Prudente (1999) }\end{array}$ \\
\hline
\end{tabular}

\footnotetext{
" By multiplying factors 2.44 to normalize the concentrations expressed as "Sn" to "TBT ion" and 0.2 to normalize the concentrations based on "dry weight" to "wet weight" (these factors are calculated from molecular weights of Sn and TBT ion and representative moisture percentage of $80 \%$ in mollusc tissue, respectively).
} 
of $0.25 \mu \mathrm{g} / \mathrm{kg} /$ body weight/day. Belfroid, Purperhart, and Ariese (2000) suggested tolerable average residue levels (TARLs) for TBT (also for DBT because of their comparable effect for mammals) in seafood to assess a risk to humans, TARLs can be calculated as a combined TDI for TBT and DBT:

TARL $=\frac{(\text { TDI } \times 60 \mathrm{~kg} \mathrm{bw})}{\text { average daily seafood consumption }}$.

According to the average seafood consumption (68.8 g/day, FAO, 1997-1999), TARL for seafood in China is estimated to be $90.8 \mathrm{ng} \mathrm{Sn} / \mathrm{g}$ for a common person with a weight of $60 \mathrm{~kg}$. The sum of TBT and DBT concentrations herein ranged from $<2.5$ to $397.6 \mathrm{ng} \mathrm{Sn} / \mathrm{g}$ (mean $60.9 \mathrm{ng} \mathrm{Sn} / \mathrm{g}$ ). The average BTs contamination level was lower than the TARL value, however, those in some of heavily polluted samples (occupied about $20 \%$ of the total samples) exceeded the proposed norm. It should be noted that the daily seafood consumption per capita used in the calculation of TARLs is based on the average levels. This implies that part of the population, such as fishermen or people with seafood preferences consuming larger amounts of seafood than the average, may be at higher risk to organtin exposure.

\section{Acknowledgements}

This work was jointly supported by the National Natural Science Foundation of China (20205008, 20137010) and the Chinese Academy of Sciences (KZCX2-414).

\section{References}

Albalat, A., Potrykus, J., Pempkowiak, J., \& Porte, C. (2002). Assessment of organotin pollution along the Polish coast (Baltic Sea) by using mussels and fish sentinel organisms. Chemosphere, 47, $165-171$.

Belfroid, A. C., Purperhart, M., \& Ariese, F. (2000). Organotin levels in seafood. Marine Pollution Bulletin, 40, 226-232.

Chau, Y. K., Maguire, R. J., Brown, M., Yang, F., Batchelor, S. P., \& Thompson, J. A. J. (1997). Occurrence of butyltin compounds in mussels in Canada. Applied Organometal Chemistry, 11, 903-912.

Chin, S. T., Ho, L. M., \& Wong, P. S. (1991). TBT contamination in Hong Kong waters. Marine Pollution Bulletin, 21, 220-227.

De Mora, S. J., Fowler, S. W., Cassi, R., \& Tolosa, I. (2003). Assessment of organotin contamination in marine sediments and biota from the gulf and adjacent region. Marine Pollution Bulletin, 46, 401-409.

Falandysz, J., Wyrzykowska, B., Warzocha, J., Barska, I., GarbacikWesolovaka, A., \& Szefer, P. (2004). Organochlorine pesticides and PCBs in perch Perca fluviatilis from the Odra/Oder river estuary, Baltic Sea. Food Chemistry, 87, 17-23.

Gibbs, P. E., \& Bryan, G. W. (1996). Tributytin: case study of an environmental contaminant. In S. J. De Mora (Ed.) (pp. 212-220). Cambridge: Cambridge University Press.

Harino, H., Fukusima, M., Yamamoto, Y., Kawai, K., \& Miyazaki, N. (1998). Contamination of butyltin and phenyltin compounds in the marine environment of Otsuchi Bay, Japan. Environmental Pollution, 101, 209-214.
Hong, H. K., Takahashi, S., Min, B. Y., \& Tanabe, S. (2002). Butyltin residues in blue mussels (Mytilus edulis) and arkshells (Scapharca broughtonii) collected from Korean coastal waters. Environmental Pollution, 117, 475-486.

Hwang, H. M., Oh, J. R., Kahng, S. H., \& Lee, K. W. (1999). Tributyltin compounds in mussels, oysters and sediments of Chinhae Bay, Korea. Marine Environmental Research, 47, 61-70.

Jiang, G. B., Maxwell, P. S., Siu, K. W. M., Luong, V. T., \& Berman, S. S. (1991). Determination of butyltins in mussel by gas chromatography with flame photometric detection using quartz surfaceinduced luminescence. Analytical Chemistry, 63, 1506-1509.

Jiang, G. B., Zhou, Q. F., Liu, J. Y., \& Wu, D. J. (2001). Occurrence of butyltin compounds in the waters of selected lakes, rivers and coastal environments from China. Environmental Pollution, 115, $81-87$.

Kan-atireklap, S., Yen, N. T. H., Tanabe, S., \& Subramanian, A. N. (1998). Butyltin compounds and organochlorine residues in green mussel (Perna viridis L.) from India. Toxicology and Environmental Chemistry, 67, 409-424.

Kannan, K., \& Falandysz, J. (1997). Butyltin residues in sediments, fish, fish-eating birds, harbor porpoise and human tissues from the polish coast of the Baltic Sea. Marine Pollution Bulletin, 34, 203-207.

Fent, K. (1996). Ecotoxicology of organotins compounds. Critical Review Toxicology, 26, 1-117.

Konstantinou, I. K., \& Albanis, T. A. (2004). Worldwide occurrence and effects of antifouling paints booster biocides in the aquatic environment: a review. Environmental International, 30, 235-248.

Michael, B. (2002). Imposex and tributyltin contamination as a consequence of the establishment of a marina, and increasing yachting activities at Phuket Island, Thailand. Environmental Pollution, 117, 421-429.

Morcillo, Y., \& Porte, C. (1998). Monitoring of organotin compounds and their effects in marine molluscs. Trends in Analytical Chemistry, 77, 109-117.

Penninks, A. H. (1993). The evaluation of data-derived safety factors for bis(tri-n-butyltin)oxide. Food Additives and Contamination, 10, 351-361.

Prudente, M. S. (1999). Heavy metals, organochlorines and butyltins contamination in the Philippine environment. Ph.D Thesis, Ehime University, Japan.

Rüdel, H., Lepper, P., \& Steinhanses, J. (2003). Retrospective monitoring of organotin compounds in marine biota from 1985 to 1999: results from the German Environmental Specimen Bank. Environmental Science and Technology, 37, 1731-1738.

Sawaya, W. N., Al-Awadhi, F. A., Saeed, T., Al-Omair, A., Husain, A., Ahmad, N., et al. (2000). Dietary intake of organophosphate pesticides in Kuwait. Food Chemistry, 69, 331-338.

Shim, W. J., Hong, S. H., Yim, U. H., Kim, N. S., \& Oh, J. R. (2002). Horizontal and vertical distribution of butyltin compounds in sediments from shipyards in Korea. Archives Environmental Contamination and Toxicology, 43, 277-283.

Tong, S. L., Pang, F. Y., Phang, S. M., \& Mandlai, H. C. (1996). Tributyltin distribution in the coastal environment of peninsular Malaysia. Environmental Pollution, 91, 209-216.

Uhler, A. D., Durell, G. S., Steinhauer, W. G., \& Spellacy, A. M. (1993). Tributyltin levels in bivalve mollusks from the east and west coasts of the United States: results from the 1988-1990 national status and trends mussel watch project. Environmental Toxicology and Chemistry, 12, 139-153.

World Health Organisation. (1990). Tributyltin compounds. (p. 273). Geneva: WHO.

Zhao, R. Y., Cheng, J. M., \& Zhao, D. D. (1982). Marine mollmca fauna of Dalian. Beijing: Oceanic Publishing House.

Zhou, Q. F., Jiang, G. B., \& Qi, D. Q. (1999). Synthesis and application of propylmagnesium bromide grignard reagent in derivation of butyltin compounds. Chinese Journal of Analytical Chemistry, 27, 1197-1199. 